\title{
How Online Tutorial Can Help Distance Education Students to be More Active in Their Learning
}

\author{
Titi Chandrawati
}

Universitas Terbuka Jakarta, Indonesia

e-mail: titich@ecampus.ut.ac.id

\begin{abstract}
There are massive changes in many aspects of our life that affect our life such as in the way we learn. Universitas Terbuka (UT) is a distance education university that often uses technology for its teaching and learning activities such as online tutorial. Basically, UT students' do not meet their lecturers face to face every day. Being UT students require UT students to learn independently by reading UT learning printed materials by themselves. Moreover, UT's online tutorials are provided to help UT students in understanding their course materials. In order to investigate why and how online tutorials can help UT students while learning at a distance, so the researcher conducted this study. In addition, in this study, the researcher tried to explore how participating in online tutorial can help UT students to become more active in their learning. This study was used in the Professionalism of early childhood teachers online tutorial course. The research method for thus study was using descriptive qualitative method using online open questions which were sent to 286 participants. The data were analyzed using descriptive qualitative data analysis. Only 55 students from 286 online tutorial participants who answered the questions. The results of this study were 1. participating in online tutorial apparently can be a way to help the students understanding the course material, 2. Participating in online tutorial can motivate and help UT students to be more active in their learning and 3. By learning online, students learn to get used with computers and internet.
\end{abstract}

Keywords: UT, online tutorial, learning online, learning independently

\section{INTRODUCTION}

We are now living in a digital age surrounded by massive changes in many aspects of our life. The changes affect our life such as in the way we relate to each other and in the way we learn (Bates, 2015). The rapid changes in technology has certainly affected all aspects of our life which certainly affect the Indonesian government policies including in education.

The government policies for higher education has been implemented by UT since UT was established in 1984. In UT web (https://www.ut.ac.id/en/brief-history) it is stated that Universitas Terbuka (UT), the $45^{\text {th }}$ state university in Indonesia, "is entirely using distance education mode of learning.
Since the beginning, UT has been designed to be a university serving people who lack the opportunity to attend face-to-face mode of higher education system due to various constraints, including lack of funding, living in isolated and rural areas, and work as well as other commitments. The UT system has continued to evolve and improve in terms of its teaching and learning systems, management, and support services for students".

Due to the rapid technology improvement, UT continuously undergoes change, innovation, and improvement. UT uses the technology in response to the changing demands by clients and stakeholders such as by UT's students (https://www.ut.ac.id/en/brief-history). It is the reason why in UT, technology is really used to manage all aspects of UT instructional system such 
as in providing online teaching and learning process that is called online tutorial (tutorial online or tuton). Being UT students mean the students have to learn independently since UT students' do not meet their lecturers or instructors directly face- to- face every day. Online tutorial is provided to help UT students in understanding their course materials while learning independently. In learning via online, students can learn in their own place without leaving their classes or their family and in their own time.

The provision of online tutorial for Early childhood educators is started since 2007/2008. But in that time there were only very few ECE student teachers participated in learning online. In 2013 there were more ECE student teachers joined the online tutorial. In 2018, UT ECE student teachers who participated in online tutorial especially in Professional from In order to investigate why and how online tutorials can help UT students while learning at a distance, the researcher conducted this study. In addition, in this study, the researcher tried to explore how participating in online tutorial can help UT students to become more active in their learning.

\subsection{Indonesian policies for higher education in Industrial revolution 4.0}

The rapid development of technology is realized by the Ministry of Research and Technology and Higher Education. Therefore, when there was a National Working Meeting (Rakernas) held in the beginning of 2018, the Minister explained that:

"the world are now entering the industrial revolution era 4.0 or the fourth world industrial revolution where information technology has become the basis for human life. Everything becomes borderless with unlimited computing and data usage, because it is influenced by the development of the internet and massive digital technology as the backbone of human and machine movement and connectivity. This era will also disrupt various human activities, including the fields of science and technology (science and technology) and higher education (https://www.ristekdikti.go.id/pengembangan-iptekdan-pendidikan-tinggi-di-era-revolusi-industri-4O/)"

Moreover, the minister of Ministry of Research and Technology and Higher Education stated that one of the five important elements that must be considered in order to enter the 4.0 Industrial Revolution era, is:

"Preparation of a more innovative learning system in universities such as adjusting the learning curriculum, and improving students' abilities in terms of data Information Technology (IT), Operational Technology (OT), Internet of Things (IoT), and Big Data Analitic, integrating physical objects digital and human to produce competitive and skilled college graduates especially in the aspect of data literacy, technological literacy and human

literacy.(https://www.ristekdikti.go.id/pengembanga n-iptek-dan-pendidikan-tinggi-di-era-revolusiindustri-4-0/)"

The use of digital technology in Indonesia is many around more than 55 million people are using smart phone or tablets and laptop (Belawati, 2015).

\subsection{Digital learning at UT}

Since 1984 UT has already used technology in managing its educational system. The improvement of technology helps UT to develop its learning system which based in digital technology such as providing digital library, smart teacher portal, online examination and including online tutorial. has provided Indonesian people and the students with many aspects of distance education. In line with the policy of the Ministry of Research and Technology and Higher Education, UT has used technology and using digital in many factors of its operation system such as for online tutorial, registration, library, examination, delivering courses and information. UT also saves all the data in digital form.

\subsection{UT online tutorial}

Actually, UT has provided some services to help UT students learning at UT for example faceto-face tutorial, online tutorial, radio tutorial, and television tutorial as part of UT's learning support. However, this paper only study about online tutorial, even though, it is apparent that face-to-face tutorial is the most preferred mode of tutorial by students especially students in the Basic education.

In UT, the online tutorial is provided for courses that do not have a face to face tutorial. Online tutorial is carried out for eight sessions or eight weeks (two months). Nowadays, the online tutorial is offered for many courses in all study programs. All students are able to participate in the 
online tutorial. During the tutorial, students are able to discuss with the tutors and the other students both synchronously and asynchronously (https://www.ut.ac.id/en/tutorials).

Students can get more info about the services through UT web, www.ut.ac.id. In addition, as UT students, early childhood educators or teachers can register to participate in online tutorial. One thing that should be known by the student if they want to join and participate in online tutorial is the students must have an e - mail address with their username and password. It is suggested that the students have to have Gmail email address to participate in online course more easier.

Online tutorial will be provided in eight weeks. Each week the students should learn one initiation and one discussion topic. The assignments will be provided in the third, fifth and seventh week. Thus, it will be eight learning materials, five to six discussion topics and three assignments. In participating in online tutorial, the students can have dialogue in the online discussions (questions and answers) with the online tutor and with their fellow students.

The interaction among students and their online tutors can be considered as the learning process for UT students, besides reading the learning printed materials (module). Students can dialogue either with their online tutors, their colleagues, or the course material module. Participating in online tutorial will contribute $30 \%$ to the students' final grade of the course.

\subsection{Dialogue based teaching and learning activities in online tutorial}

Bento (2005) informed that usually students who enroll in an online learning program will feel isolated if the teachers (instructors) only use an asynchronous one way communication or transmitting information or knowledge. In asynchronous online learning, students can only listen and do whatever the teachers ask them to do or to listen. This kind of communication will not allow the participants (teachers, students) to reflect, to share their opinion to make meaning together; yet, in online learning where dialogue is provided, students can share and learn their other students ideas, for example by reading the other students' posting; students can also learn from the contents material that they learn and from their teachers.
By using dialogue in online learning, students can reflect and also can learn from " point made by classmates and inquire and reflect on them". Students can gain insight by learning from their friends, they can make meaning together by learning from each other's postings. "By approaching another student's work with a "beginner's mind" - and by not assuming that they are sure what the other students are thinking - they allow themselves and their classmates to make fresh starts with the material and see things differently.

Education is social relation. And the heart of the social relation is dialogue. Freire (in Burbules, 1993, p.6) emphasized that teaching learning activity should be dialogical because teaching and learning activity should be a process of shared inquiry, not the transmission of truths from a knowledgeable expert to a passive recipient. It means that dialogue will make the instructional activity as transformative. This transformative instruction will help students to become actively involved in learning any learning materials and learning in their own environments. As well, in dialogue there is a shift of power to the students such that they feel more engaged as equals in a process of inquiry. Dialogue is not about simply transmitting knowledge to students, but more importantly about transforming students through their engagements with their lived realities and with each other as stated by Freire (1970/2010).

It is hoped that this kind of learning will help students to engage in their learning since dialogue in online learning, according to Scott et al. (2008) will create full attention, interaction, consciousness, critical thinking, active learning and a mutual respect between teachers-students or studentsstudents, and all of these qualities will help students $\&$ teachers engage in the online learning to conceptualize the meanings.

How participating in online tutorial could help UT early childhood student teachers for their continuing professional development.

To help students for the $21^{\text {st }}$ century work and citizenship, 'teacher professional development in every country should include methods to improve the effectiveness of schools as they are, but should also focus on transformational strategies for developing deeper forms of content, new model of pedagogy, and organizational partnership for learning with parents, businesses, and community institutions" (Dede, 1998, in Vrasidas \& Glass, 2004, p.xii). 
Teacher professional development can be viewed as an important factor for moving education toward better future. According to Vrasidas \& Glass (2004, p.2-3) some characteristics of effective professional development can be seen when students' actively engaged in meaningful activities and when they reflect critically on what they are doing. These characteristics can also be used in teacher professional development. To develop an effective professional development for studentteachers, it is believed that we need to move our teaching and learning process toward pedagogical models that value interaction among participants, the social nature of learning, community, and reflection in practice. In distance education setting, this shift will change the traditional instruction that always be used by distance education institution that is the use of the learning materials that ignored interaction among students and tutors.

Online learning in distance education can be divided into asynchronous and synchronous. Executing synchronous is rather difficult compared with asynchronous. It is difficult to do a synchronous online learning since all participants have to arrange the same time in order to make them can meet to each other directly. Therefore, in UT online tutorial asynchronous online learning program has often been used.

Dialogue approach in online learning program is hoped can be applied to be an effective teacher professional development. Online program can also help students who want to learn anywhere, any time (Vrasidas \& Glass, 2004, p.4). Professional development can help overcome shortcomings that may have been part of teachers' education and keep teachers use of new knowledge and practices in the field (UNICEF, 2000). It should be noted that dialogue and reflections with colleagues, peer and supervisor observations and keeping journals are all effective ways for teachers to advance their knowledge (UNICEF, 2000) in http://www.unicef.org/education/files/QualityEducat ion.PDF). UNICEF (2000) also writes that an example of a programme in Kenya, the Mombassa School Improvement Project, built on this approach to professional development and showed that teachers supported with in-service as well as external workshop training improved significantly in their abilities to use child-centred teaching and learning behaviours.

\section{METHOD}

This study was conducted to the student teachers who took online tutorial in the Professionalism of early childhood teachers online tutorial course. The respondents of this study were UT ECE student teachers who registered and participated in three classes of the Professionalism of early childhood teacher online tutorial course. For this study, the respondents were given few questions about participating in online tutorial. The research method for this study was descriptive qualitative method using online open questions which were sent to 286 participants. Qualitative approach was used since in qualitative approach the researcher tried to understand a situation, so the researcher took a single case to study, a case unique in some respects, and emphasizes the nature of that particular case (Stake, 2010, p. 19). Here, the researcher really put as an effort to understand the respondents' feelings when they were participating in online tutorial.

The data were analyzed using descriptive qualitative data analysis. There were only 55 students from 286 online tutorial participants who answered the questions via online.

\section{RESULT AND DISCUSSION}

All responses from this study respondents can reveal that participating in online tutorial, the researcher can get the information that the results of this study were:

1. Participating in online tutorial apparently can be a way to help the students understanding the course material, 2.Participating in online tutorial can motivate and help UT students to be more active in their learning and

3. By learning online, students learn to get used with computers and internet.

\section{CONCLUSION}

Dialogue in the online learning tutorial can help establish ECE at UT as a transformative, problem-posing praxis. Providing dialogue can help close the gaps and deepen understanding between students and instructors and between students themselves - and ultimately between ECE students and the children they will work with. 


\section{REFERENCES}

[1] Bates, A.W. (2015), Teaching in a Digital Age, EBOOK, Tony Bates Associates Ltd. ISBN 978-0-9952692-0-0

[2] Bento, R., Brownstein, B., Schuster, C., \& Zacur, S. (2005). Fostering online student participation. Journal of College Teaching \& Learning, 2(7), 31-38.

[3] Burbules, N. C. (1993). Dialogue in teaching: Theory and practice. New York, NY: Teachers College Press.

[4] Caspi, A., \& Gorsky, P. (2006). Instructional dialogue: Distance education students' dialogic behaviour. Studies in Higher Education, 31(6), 735-752.

[5] Prakoso, T., \& Suciati (2015). UT in the information era. Universitas Terbuka: Jakarta.

[6] Price, F. F. (2012, March 29-April 4). Is that how you talk to a child? Vancouver, BC: The Epoch Times, Vancouver Edition.

[7] Rossman, G. B., \& Rallis, S. F. (2011). Learning in the field: An introduction to qualitative research (3rd ed.). Thousand Oaks, CA: Sage.
[8] Scott, C. F. (2011). Becoming dialogue; Martin Buber's concept of turning to the other as educational praxis (Doctoral dissertation). Retrieved from http://summit.sfu.ca/item/11608.

[9] Shields, C. M., \& Edwards, M. M. (2005) Dialogue is not just talk: A new ground for educational leadership. New York, NY: Peter Lang.

[10] Simonson, M., Smaldino, S., Albright, M., \& Zvacek, S. (2009). Teaching and learning at a distance: Foundations of distance education (4th ed.). New York, NY: Pearson.

[11] Sparks, D. (2002). Designing powerful professional development for teachers and principals. Oxford, OH: National Staff Development Council. Retrieved from http://www.friscoisd.org/ly/departments/profess ionalDev/documents/DesigningPowerfulProfess ionalDevelopmentforTeachersandPrincipals_00 0 .pdf

[12] Stake, R. (2010). Qualitative research: Studying how things work. London: The Guilford Press.

[13] https://www.ut.ac.id/en/tutorials

[14] https://www.ristekdikti.go.id/pengembanganiptek-dan-pendidikan-tinggi-di-era-revolusiindustri-4-0/. 